\title{
Lost in Between: \\ The Case of Russian Heritage Speakers
}

\author{
Ludmila Isurin, Ohio State University \\ Tanya Ivanova-Sullivan, University of New Mexico
}

\begin{abstract}
The present paper looks at the growing population of Russian heritage speakers from a linguistic and psycholinguistic perspective. The study attempts to clarify further the notion of heritage language by comparing the linguistic performance of heritage speakers with that of monolinguals and second language learners. The amount of exposure to L1/L2, the age at which immigration to the U.S. occurred, degree of literacy in Russian, and metalinguistic awareness were among the sociolinguistic factors considered in the present study. The qualitative in-group and cross-group analyses revealed syntactic and morphological features that characterize Russian as a heritage language. The performance of heritage speakers on the narrative task differed from that of Russian monolinguals and American learners of Russian.
\end{abstract}

\section{Introduction}

Over the past 15 years there has been growing interest in the language of heritage speakers (HS). Researchers have increasingly emphasized the special linguistic behavior and needs of HS, which are claimed to be distinct from those of traditional students. However, there is still a lack of empirical research on HS. Studies on Russian heritage speakers range from comparing the language use of the four waves of Russian immigration (Andrews, 1999; Zemskaja, 2001) to giving a descriptive analysis of the problems exhibited by Russian heritage speakers in the American classroom (Andrews, 2000; Bermel \& Kagan, 2000). Other American scholars have reached practical solutions for teaching heritage speakers their home language in the U.S. (Kagan, Akishina, \& Robin, 2002). In 2004-2005 two major professional venues, AATSEEL in Philadelphia, and AILA in Madison, Wisconsin, hosted panels on Russian in Diaspora. These events can be viewed as an additional indicator of the growing interest in the Russian language and its speakers overseas. However, the insufficient amount of research done in the field, the lack of empirical evidence (Ke, 1998), and the very problem of defining a "heritage speaker" (KondoBrown, 2002) have been identified as unresolved issues in previous studies.

The present paper looks at the growing population of Russian heritage speakers from linguistic and psycholinguistic perspectives. ${ }^{1}$ By adopting such an approach, we further define the notion of heritage language by comparing the linguistic performance of heritage speakers with that of monolingual speakers as well as second language (L2) learners. 


\section{Experimental Study}

\subsection{Participants}

The subjects of our study have been described in the literature as speakers of American Russian (cf. Polinsky 2000a), i.e., either immigrants from the former USSR who came to the U.S. before the critical age of 10, or people born in the U.S. to Russian-speaking parents. Research participants meeting these criteria were defined as heritage speakers of Russian $(n=7)$. Two other groups of subjects participated in the study: a) English speakers who are advanced learners of Russian $(\mathrm{n}=11)$, and $\mathrm{b})$ a control group of monolingual Russian speakers $(\mathrm{n}=5)$. The heritage speakers and L2 learners of Russian were recruited from the pool of students at Ohio State University. The group of L2 learners consisted of English-speaking graduate students who had majored in Russian and whose academic career required a knowledge of the Russian language. It should be noted that an oral proficiency test was not administered to the L2 learners. However, we worked under the assumption that a proficiency level no lower than intermediate high is a prerequisite for admission to the graduate program from which our L2 participants were drawn. The participants in the heritage speaker group were given extra credit for their participation. The control group was recruited from monolingual speakers of Russian residing in St. Petersburg, Russia. The age, social, and educational background of all participants were comparable.

\subsection{Material}

\subsubsection{Background Questionnaire}

A background questionnaire administered prior to the study was aimed at gathering languagerelated information. Students were asked to respond to questions on topics including the amount of their exposure to L1/L2, age at immigration to the U.S., language spoken to parents, degree of literacy in Russian, contacts within Russia, motivation to maintain/learn Russian, and metalinguistic awareness.

\subsubsection{Stimuli}

A children's picture book, A boy, a dog, a frog and a friend by Mayer and Mayer (1978), provided the test stimuli. The book is one in a series of so-called frog stories that has been successfully used in psycholinguistic studies on narrative discourse. The frog methodology was first used in a crosslinguistic developmental study on 5 different languages (Berman \& Slobin, 1994) and later adopted by other scholars in studies on heritage learners language (Polinsky, 2008) and first language attrition (Olshtain \& Barzilay, 1991; Isurin, 2005).

\subsection{Task}

We used a controlled narration task to elicit speech samples. Subjects were offered the children's picture book and asked to tell a story based on the events chronologically depicted in the book. However, we have somewhat changed the original methodology. The focus of the present research was not on eliciting connected discourse and finding the critical features of a narrative mode of discourse (Berman \& Slobin, 1994). Rather, our goal was to detect morphosyntactic difficulties experienced in unrehearsed narration. Thus, contrary to the methodology used in previous studies in which participants were asked to look through the entire book prior to telling the story (Berman \& Slobin, 1994; Olshtain \& Barzilay, 1991; Polinsky, 2008), ${ }^{2}$ our participants were specifically instructed not to do so. Instead, they were to tell the story as the events unfolded via each picture. 
We believe that the use of unrehearsed narration methodology reveals linguistic problems that possibly would not have been detected had the subjects been given a chance to think about the content in advance. Advanced planning could also lead to avoidance strategies (Olshtain \& Barzilay, 1991). On the other hand, we are aware that there are certain risks in using such a task; namely, the very nature of the narration of unfolding events depicted in a book could influence certain syntactic patterns in the participants' grammar that otherwise may not have surfaced. We will address these problems in the sections below on the findings of our study.

\subsection{Procedure}

Subjects were interviewed individually. Prior to the interview, they were asked to fill out the background questionnaire. They were then asked to narrate a story page by page (remember that they were not allowed to see how the events unfold in the book in advance). Their performance was tape recorded and later transcribed and analyzed. No answers were cued or prompted by the researchers. The data were analyzed qualitatively. The focus of the in-group analysis was to find those lexical, syntactic, and morphological features that characterize the linguistic performance of Russian heritage speakers. In a cross-group analysis we then attempted to shed light on the linguistic uniqueness of heritage speakers and their place in the continuum of language speakers.

\section{Findings: Heritage Speakers ${ }^{3}$}

Table 1 presents our findings of deviations from standard Russian by HS in both percentages (based on the total number of occurrences of any given category) and raw numbers (the actual number of errors in each category). The order of categories is descending, i.e. from the category with the most errors to the one with the fewest, an arrangement that helps us grasp the bigger picture of the speakers' performance.

Moreover, we would expect to have some specific morphosyntactic categories elicited under such a task and not others. ${ }^{4}$ We therefore limit our analysis to only a few morphosyntactic categories that occurred most frequently in the speech of our participants and that may indicate general trends in heritage speakers along the continuum from monolingual speakers of Russian to L2 learners. Since these morphosyntactic categories will be compared across the three groups, we will pursue a more detailed analysis of those categories when comparing the HS performance with another experimental group, L2 learners.

The lexical knowledge of the heritage speakers was not an object of study in this work. A complete study of the lexicon would require a different approach (i.e., different task and materials) or larger and more versatile samples. However, we realize that vocabulary is an important component of the overall profile of heritage speakers and that its range could interfere with the morphosyntactic data. Thus, we will briefly discuss the data on vocabulary in a section below. 
Table 1. HS Deviations from Standard Russian: Major Findings

\begin{tabular}{|l|c|c|c|}
\hline Category & Instances in \% & Instances in Numbers & Number of Speakers \\
\hline Aspect & $4.1 \%$ & 17 & 5 \\
\hline Case & $2.4 \%$ & 19 & 5 \\
\hline Word order (VS) & $2.1 \%$ & 8 & 6 \\
\hline
\end{tabular}

\subsection{Grammatical Findings}

\subsubsection{Aspect}

The HS narratives reveal alternations of tense and aspect within the same utterance that are uncharacteristic of standard Russian. Note the following examples:

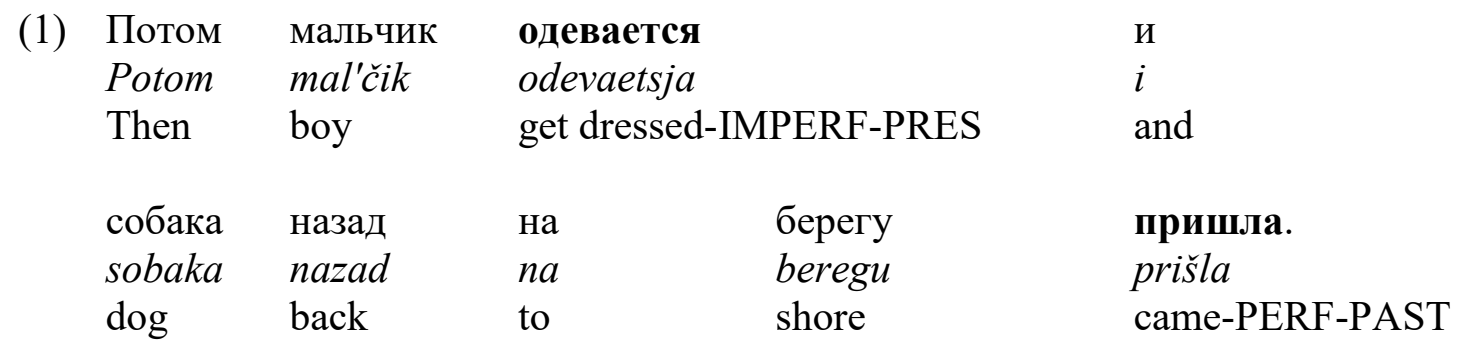

'Then the boy is getting dressed / got dressed and the dog is coming / came back to the shore.'

$\begin{array}{lll}\text { (2) Рыба взяла } & \text { крючок } & \text { и мальчик } \\ \text { ryba vzjala } & \text { krjučok } & i \text { mal'čik } \\ \text { Fish take-PERF-PAST } & \text { fishhook } & \text { and boy } \\ & & \\ \text { тянет, } & \text { тянет, } & \text { рыбу. } \\ \text { tjanet } & \text { tjanet } & \text { rybu } \\ \text { pull-IMPERF-PRES } & \text { pull- IMPERF-PRES fish }\end{array}$

'The fish took the fishhook and the boy pulled the fish out.' 


$\begin{array}{llll}\text { (3) Мальчик } & \text { растерялся } & \text { a } & \text { как будто-то, } \\ \text { Mal'čik } & \text { rasterjalsja } & \text { kak budto-to } \\ \text { boy } & \text { get upset-PERF-PAST } & \begin{array}{l}\text { and } \\ \text { apparently }\end{array} \\ \text { oн } & \text { боится, } & \text { что } \\ \text { on } & \text { boitsja } & \text { čto } \\ \text { he } & \text { is afraid-IMPERF-PRES } & \text { that } \\ \text { coбaка } & \text { утонет. } & \\ \text { sobaka } & \text { utonet } & \\ \text { dog } & \text { drown-PERF-FUT } & \end{array}$

'The boy got upset and apparently was afraid that the dog would drown.'
(4) Черепаха осталась
в воде, она плавает.
Cerepaxa ostalas'
$v$ vode, ona plavaet

Turtle remain-PERF-PAST in water, she swim-IMPERF-PRES.

'The turtle remained in the water, it was swimming.'

We observed very few examples of aspectual forms that would be clearly non-permissible in Standard Russian, such as the use of perfective to express iterative action, e.g.:

$\begin{array}{clllll}\text { (5) Он } & \text { потянул } & \text { и } & \text { потянул } & \text { на } & \text { удочку } \\ \text { on } & \text { potjanul } & i & \text { potjanul } & \text { na } & \text { udočku. } \\ \mathrm{He} & \text { pull-PERF-PAST } & \text { and } & \text { pull-PERF-PAST } & \text { at } & \text { fishing rod. }\end{array}$

'He was pulling and pulling the fishing rod.'

Overall, however, the HS narration recorded in this study suggests that these speakers tend to use perfective verbs in the past tense to express accomplished actions and imperfective verbs in the present tense for ongoing actions. Polinsky, in her article on full and incomplete language acquisition, also refers to lexicalized perfectives and imperfectives, which HS choose based on telicity, i.e. the "completedness" of the action (Polinsky, 2000b). In a recent paper on heritage language narratives, Polinsky (2008) expands on the role of telicity in aspect by offering a plausible mechanism for retention of just one member of an aspectual pair. Measuring the frequency of HS use of the perfective versus imperfective in HS narratives, she concludes that "the choice of the single aspectual form, lexicalized in American Russian, may be determined by the more frequent conceptualization of a given event as telic or atelic." We should add that in our study the role of the conceptualization of telicity in the expression of aspect is further complicated by the additional component of tense. We could view the aspect/tense interplay as not only a marker of telicity but also in certain instances a narration strategy where the foreground and background events or 
actions are marked by both aspect and tense. In other words, perfective/preterit foreground the event while imperfective/present is reserved for background (secondary to the main plot) events. Nevertheless, in order to confirm such a hypothesis, this phenomenon needs to be explored further not only in narratives but in other types of discourse as well. ${ }^{5}$

In addition to the lexicalization of one member of an aspectual pair, Polinsky's results show combinations of a "light" verb (a semantically less salient auxiliary, such as begin) plus a "content" verb to express perfectivity. Such instances were not found in our HS data but were present in the L2 narratives across the board. Constructions such as načinaet padat' ('begins to fall'), načinaet snjat' odeždu ('begins to get undressed'), ešče raz načinaet plakat' i kričat' ('once more begins to cry and yell'), načinaet ssorit'sja ('begins to argue'), and načala uxodit' ('begins to leave') indicate inchoative (i.e. incipient) actions in some cases, whereas in others they are used to express an already unfolding action.

A comparison with the monolingual group in St. Petersburg shows the Standard Russian mechanisms for expressing inchoative actions: 1) the light verb stat' ('to become/begin') in the past tense, stal pomogat' ('began to help'), stala smotret' ('began to look'), stal nabljudat' ('began to observe'), stal tjanut' ('began to pull') and 2) perfective verbs with the prefixes $z a$ - or $p o$ - denoting the beginning of an action, such as zakričat' ('to begin to shout'), zagovorit' ('to begin to speak'), pobežat' ('to set off at a run') and poslušat' ('to listen, cock an ear').

\subsubsection{Case}

Heritage speakers' performance also reveals recurring problems in the use of case. Case errors are present in the speech of both heritage speakers and the L2 learners. However, there are significant differences in the nature of these errors and the possible reasons for their occurrence. In this section, we outline the most notable case errors in the heritage speakers' performance, arranged according to category:

\subsubsection{Incorrect Case of Personal Pronouns}

a) Dative instead of instrumental:

(6) Ему тяжело рыбу взять с нему. emu tjaželo rybu vzjat' $c$ nетu.

To himhard fish to take with he-PRON:DAT

'It is hard (for him) to take the fish with him.'

b) Accusative instead of instrumental:

(7) $\begin{array}{llll}. . \text { си } & \text { собака туда } & \text { пошла } & \text { за } \\ i & \text { sobaka tuda } & \text { pošla } & z a \\ \text { and } \operatorname{dog} \text { there } & \text { go-PERF-PAST } & \text { after }\end{array}$

' ... and the dog followed him there.' него.

nego

he-PRON:ACC 
(8) И потом мальчик идет домой с turtle и

I potom mal'čik idët domoj s turtle $i$

And then boy go home with turtle and

собака за него. ${ }^{6}$

sobaka za nego

$\operatorname{dog}$ after he-PRON-ACC

'And after that, the boy is going home with the turtle and the dog is following him.'

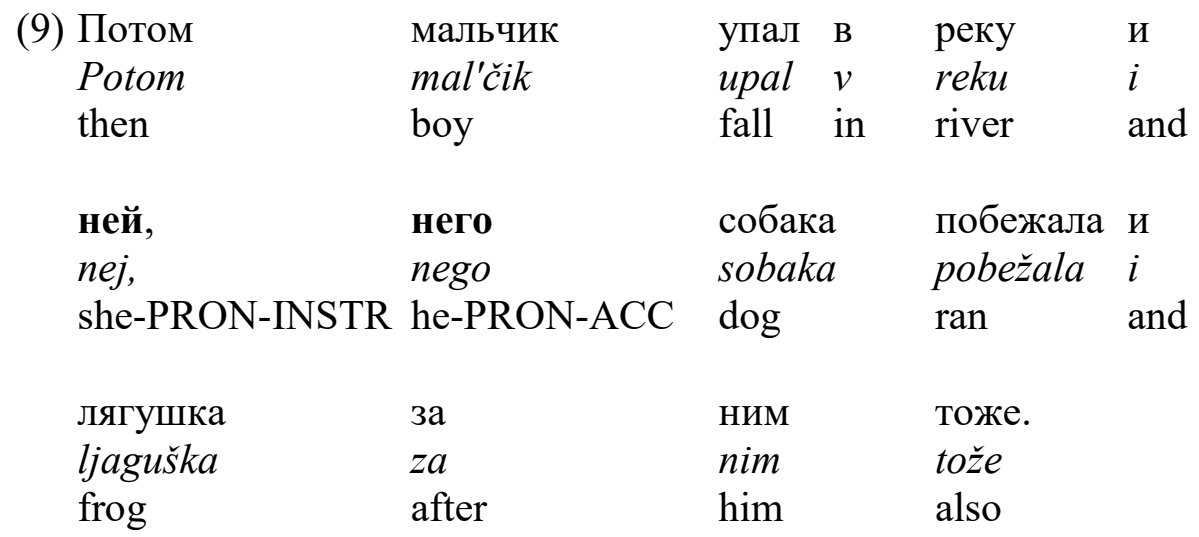

'Then the boy fell in the river and the dog and the frog ran after him.'

The L2 narratives revealed a somewhat different pattern of pronominal usage: fewer case errors but also significantly less occurrence of personal pronouns overall. The eleven L2 narratives show 20 instances of personal pronouns in various constructions ( 3 of them incorrect) versus 50 in the seven HS narratives ( 5 of them incorrect, but 4 of them were attested in the narrative of a single speaker born in the U.S.). One reason for the much smaller number of pronouns in the L2 narratives could be due to an 'avoidance' strategy (e.g., one L2 speaker did not use personal pronouns at all). ${ }^{7}$ The use or avoidance of certain vocabulary items and the resulting effects on morphosyntactic analysis are a fundamental problem in such experimental studies. Therefore, before describing other examples of HS case errors, we will briefly discuss the lexical competence of the three groups of participants.

The range of vocabulary used by HS falls somewhere in between that of L2 and monolinguals. HS as a group showed very few lexical gaps, ${ }^{8}$ mainly in verbs designating specific actions (see the section on lexical extension). In certain cases, HS used circumlocution to fill in those gaps, as shown in the following example:

(10) И потом мальчик хотел (не помню как сказать), 


\begin{tabular}{|c|c|c|c|c|c|c|}
\hline $\begin{array}{l}i \\
\text { and }\end{array}$ & $\begin{array}{l}\text { potom } \\
\text { then }\end{array}$ & $\begin{array}{l}\text { mal'čik } \\
\text { boy }\end{array}$ & $\begin{array}{l}\text { xotel } \\
\text { wanted }\end{array}$ & $\begin{array}{l}\text { (ne } \\
\text { no }\end{array}$ & $\begin{array}{l}\text { pomnju } \\
\text { remember }\end{array}$ & $\begin{array}{l}\text { kak } \\
\text { how }\end{array}$ \\
\hline так & $\mathrm{OH}$ & сделал & дырку & B & земле. & \\
\hline tak & on & sdelal & dyrku & $v$ & zemle. & \\
\hline co & he & made & hole & in & earth & \\
\hline
\end{tabular}

'And then the boy wanted (I don't remember how to say that), so he made a hole in the ground.'

In the above example the verb that the speaker is looking for is vyryt' ('to dig a hole'), which he substitutes with the more general verb sdelat' ('to make').

The narratives of the L2 learners show similar circumlocution but on a larger scale:

(11) $\mathrm{OH}$

on

$\begin{array}{llllll}\text { готовил } & \text { место, } & \text { чтобы положить } & \text { черепаху- } & \text { какое-то } \\ \text { gotovil } & \text { mesto, } & \text { ćtoby } & \text { položit' } & \text { čerepaxu } & \text { kakoe-to } \\ \text { prepared } & \text { place } & \text { for } & \text { lay } & \text { turtle } & \text { some }\end{array}$

кладбище.

kladbišče

cemetery

'He was preparing the place to lay down the turtle—-some sort of cemetery.'

(12)

$\begin{array}{llllll}\text { И } & \text { он } & \text { сделал } & \text { могилу } & \text { для } & \text { черепахи. } \\ i & \text { on } & \text { sdelal } & \text { mogilu } & \text { dlja } & \text { čerepaxi } \\ \text { and } & \text { he } & \text { made } & \text { grave } & \text { for } & \text { turtle }\end{array}$
and he made grave for turtle

'And he made a grave for the turtle.'

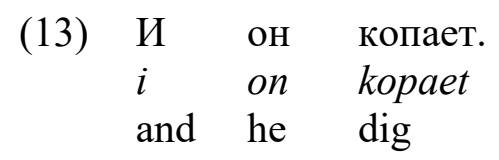

'And he is digging.' 
There were also some instances of conceptually inappropriate use of emotion words in the HS narratives. Note the following examples:

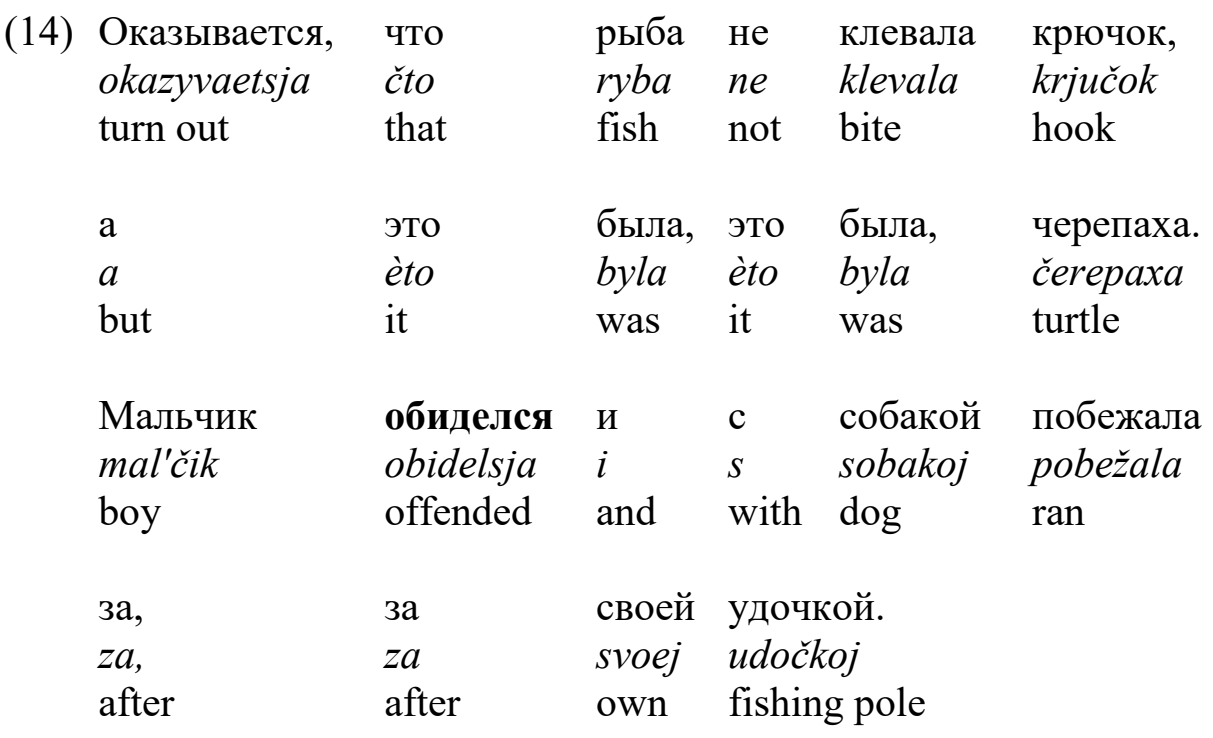

'The boy was offended/hurt and together with his dog ran after his fishing pole.'

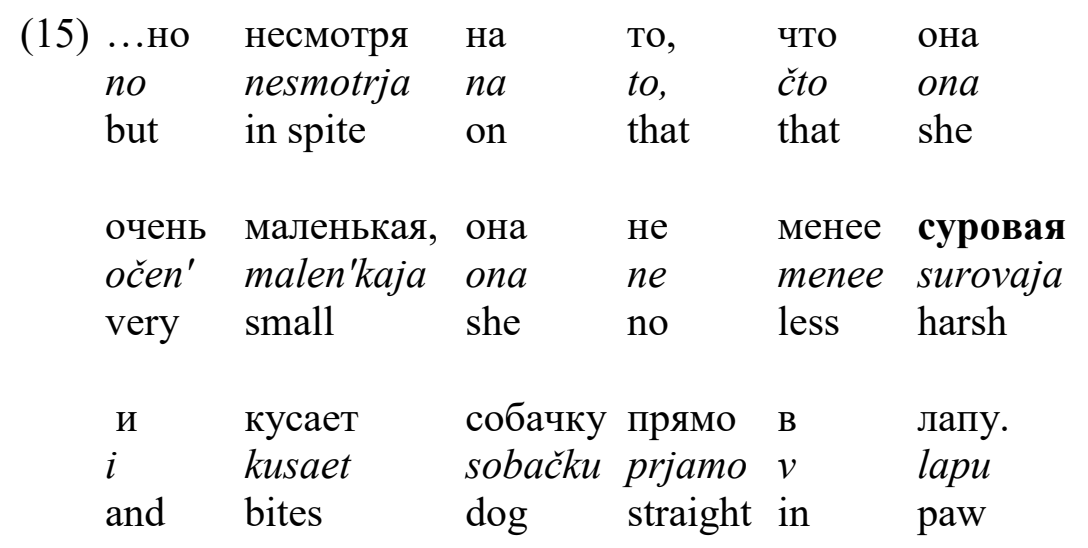

'But the turtle is no less harsh for being small and bit the dog's paw.'

By contrast, L2 learners' narratives demonstrated fewer errors in this area, probably due to the smaller number of emotion words used by that group of participants.

Vocabulary data across these two groups show that both used more or less the same core highfrequency vocabulary to express the events in the pictures. Whenever L2 learners encountered difficulties in finding a word, they would resort to circumlocution in Russian or use the English 
equivalents. It should be noted that English equivalents were used only with nouns, while circumlocution was prevalent when a specific verb had to be retrieved. The HS, however, did not exhibit quite the same patterns. They clearly had fewer lexical gaps and in only one case (the speaker born in the U.S.) did they resort to English words to fill in for the Russian. In addition, they had a more diversified range of vocabulary than the L2 learners, including the use of synonyms. Not only did they describe the events chronologically but they also interpreted them, using a full range of lexical, syntactic, and discourse means such as adjectives, various types of subordinate clauses, particles, interjections, etc. Comparison with the monolinguals' narratives reveals the same overall interpretive strategies, albeit on a larger scale among the latter.

All in all, the HS' range of lexicon was closer to that of the monolingual group than to the L2 speakers'. This fact, together with the longer duration of the HS narratives in comparison to the L2 group, could be viewed as partially responsible for the final results of our study, and particularly for some morphosyntactic patterns in the areas of pronominal case and verbal aspect. We will return to this topic in the section below on cross-group analysis.

\subsubsection{Case Errors in Nouns and Adjectives}

a) Lack of 'direction-location' distinction, expressed by accusative and prepositional cases, respectively: ${ }^{9}$

\begin{tabular}{|c|c|c|c|}
\hline $\begin{array}{l}\text { Потянула } \\
\text { potjanula } \\
\text { pull-PERF-PAST }\end{array}$ & $\begin{array}{l}\text { мальчика } \\
\text { mal'čika } \\
\text { bоy }\end{array}$ & $\begin{array}{l}\text { через } \\
\text { čerez } \\
\text { through }\end{array}$ & $\begin{array}{l}\text { воду } \\
\text { vodu } \\
\text { water }\end{array}$ \\
\hline $\begin{array}{l}\text { другой, } \\
\text { drugoj } \\
\text { other-PREP:FEM }\end{array}$ & $\begin{array}{l}\text { на } \\
\text { na } \\
\text { to }\end{array}$ & $\begin{array}{l}\text { другой } \\
\text { drugoj } \\
\text { other }\end{array}$ & $\begin{array}{l}\text { сторону. } \\
\text { storony } \\
\text { side-ACC:FEM }\end{array}$ \\
\hline
\end{tabular}

'[The turtle] pulled the boy through the water to the other side.'

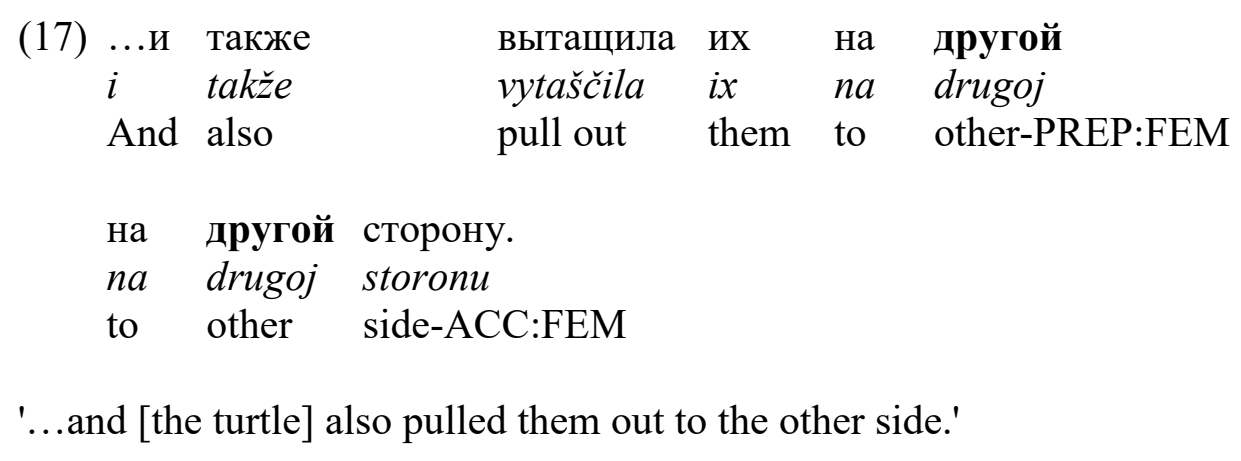


(18)

$\begin{array}{llllll}\text {...собака и } & \text { лягушка } & \text { обратно в } & \text { воде. } \\ \text { sobaka } i & \text { ljaguška } & \text { obratno } & v & \text { vode } \\ \operatorname{dog} & \text { and } & \text { frog } & \text { back } & \text { to } & \text { water-PREP:FEM }\end{array}$

'...the dog and the frog [went] back to the water.'

$\begin{array}{lllll}\text { Собака } & \text { назад } & \text { на } & \text { берегу } & \text { пришла. } \\ \text { sobaka } & \text { nazad } & \text { na } & \text { beregu } & \text { prišla } \\ \text { dog } & \text { back } & \text { to } & \text { shore-PREP:MASC } & \text { came }\end{array}$

' The dog went back to the shore.'

b) Lack of instrumental case in predicative function and after the verb stat' ('to become') (this verb requires instrumental case in Standard Russian):

(20) Все стали друзья.

vse stali druz'ja

all become friends-NOM:PL

'They all became friends.'

c) Relative clauses with kotoryj ('who', 'that', 'which' in subordinate clauses):

\begin{tabular}{|c|c|c|c|c|c|}
\hline A & тянула & их & К & берегу & большая \\
\hline $\begin{array}{l}a \\
\text { and }\end{array}$ & $\begin{array}{l}\text { tjanula } \\
\text { pull }\end{array}$ & $\begin{array}{l}i x \\
\text { them }\end{array}$ & $\begin{array}{l}k \\
\text { to }\end{array}$ & $\begin{array}{l}\text { beregu } \\
\text { shore }\end{array}$ & $\begin{array}{l}\text { bol'šaja } \\
\text { big }\end{array}$ \\
\hline $\begin{array}{l}\text { черепаха, } \\
\text { čerepaxa } \\
\text { turtle }\end{array}$ & $\begin{array}{l}\text { которая } \\
\text { kotoraja } \\
\text { which }\end{array}$ & $\begin{array}{l}\text { они } \\
\text { oni } \\
\text { they }\end{array}$ & $\begin{array}{l}\text { поймали } \\
\text { pojmali } \\
\text { caught }\end{array}$ & $\begin{array}{l}\text { вместо } \\
\text { vmesto } \\
\text { instead }\end{array}$ & $\begin{array}{l}\text { рыбы. } \\
\text { ryby } \\
\text { fish }\end{array}$ \\
\hline
\end{tabular}

'And they were pulled ashore by a big turtle, which they had caught instead of a fish.'

In Standard Russian, the relative pronoun kotoryj refers back to the noun in the matrix clause; it is co-referential with that noun but receives its case according to the structure of the subordinate clause. According to this rule, in the above-listed example from a HS narrative, kotoryj should be in accusative rather than nominative case. We could suggest two possible explanations for this error - the close proximity of the referent of kotoryj in the previous clause, and/or the nominative as a 'frozen' form for kotoryj in the grammar of this particular speaker. However, it is impossible to draw firm conclusions since there were only two instances of relative clauses with kotoryj in this speaker's narrative, one of which involves the correct case form of the relative pronoun: 


\begin{tabular}{|c|c|c|c|c|c|}
\hline 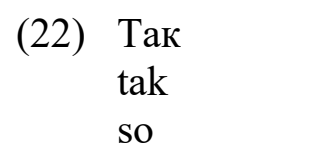 & $\begin{array}{l}\text { что } \\
\text { čto } \\
\text { that }\end{array}$ & $\begin{array}{l}\text { Сема } \\
\text { Sema } \\
\text { Sema }\end{array}$ & $\begin{array}{l}\text { подобрал } \\
\text { podobral } \\
\text { picked up }\end{array}$ & $\begin{array}{l}\text { собаку } \\
\text { sobaku } \\
\text { dog }\end{array}$ & $\begin{array}{l}\text { и } \\
i \\
\text { and }\end{array}$ \\
\hline понес & ee & B & реку & вместе & $\mathrm{c}$ \\
\hline $\begin{array}{l}\text { pones } \\
\text { carried }\end{array}$ & $\begin{array}{l}e e \\
\text { her }\end{array}$ & $\begin{array}{l}v \\
\text { to }\end{array}$ & $\begin{array}{l}\text { reku } \\
\text { river }\end{array}$ & $\begin{array}{l}\text { vmeste } \\
\text { together }\end{array}$ & $\begin{array}{l}s \\
\text { with }\end{array}$ \\
\hline $\begin{array}{l}\text { черепахой, } \\
\text { с̌еrepaxој } \\
\text { turtle }\end{array}$ & $\begin{array}{l}\text { которая } \\
\text { kotoraja } \\
\text { which-PRON:NOM }\end{array}$ & $\begin{array}{l}\text { до } \\
\text { do } \\
\text { until }\end{array}$ & $\begin{array}{l}\text { сих } \\
\text { six } \\
\text { this }\end{array}$ & $\begin{array}{l}\text { пор } \\
\text { por } \\
\text { time }\end{array}$ & $\begin{array}{l}\mathrm{y} \\
u \\
\text { at }\end{array}$ \\
\hline $\begin{array}{l}\text { него } \\
\text { nego } \\
\text { him }\end{array}$ & $\begin{array}{l}\text { на } \\
\text { na } \\
\text { in }\end{array}$ & $\begin{array}{l}\text { лапе. } \\
\text { lape } \\
\text { paw }\end{array}$ & & & \\
\hline
\end{tabular}

'So Sema picked up the dog and carried it to the river together with the turtle, which is still in its paw.'

Nevertheless, the scarcity of relative clauses with kotoryj in the HS narratives and the occasional case errors with kotoryj where it is used could be important signs of a decline in relativizing structures. ${ }^{10}$

\subsubsection{Confusion of Oblique Cases}

a) Dative instead of accusative:

(23) Маленький malen'kij

little

морю.

morju

sea-DAT:NEUT

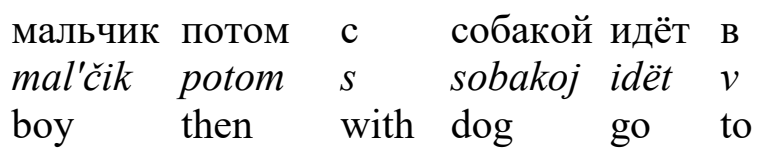

'Then the little boy and the dog went to the sea.'

Despite the obvious error, we suspect that the confusion here pertains to the choice of preposition rather than to the case ending itself. The Agent characteristic [+ animate] in this sentence, the semantics of motion, and the lexical semantics of the word more are all factors that would contribute to the selection in Standard Russian of the preposition $k$ ('toward') plus dative morju. ${ }^{11}$ 
b) Prepositional or dative (the forms are the same for feminine nouns) instead of genitive:

$\begin{array}{llll}\text { Сидит } & \text { мальчик } & \text { возле } & \text { реке. } \\ \text { sidit } & \text { mal'čik } & \text { vozle } & \text { reke } \\ \text { sit } & \text { boy } & \text { around } & \text { river-GEN:FEM }\end{array}$

'The boy is sitting by the river.'

c) Instrumental instead of prepositional:

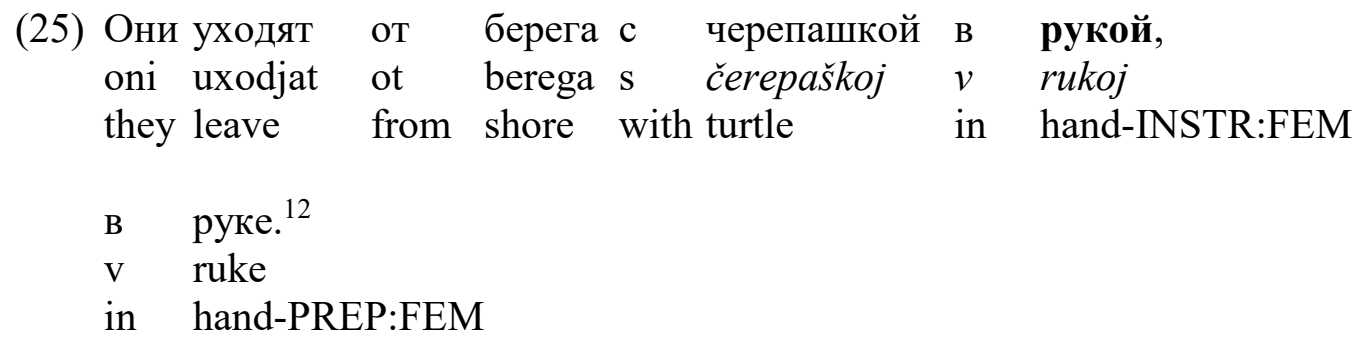

'They are leaving the shore with the little turtle in their hands.'

The above examples show the presence of oblique case forms in the grammar of heritage speakers but a lack of grammatical competence as to how and when to use them. Polinsky (2000a) argues that examples of this sort are a step towards the complete disappearance of the oblique cases in heritage speaker grammar. ${ }^{13}$ However, our study presents a more complicated picture. A comparison of our results with those obtained by Polinsky (2008) shows several differences. First, we did not observe a reanalysis of the accusative as the case of indirect objects. We indeed found some instances in which the participants used one oblique case instead of another, but by no means generalizing the accusative as the only case for indirect objects. Second, we never found nominative case occurring after prepositions. The latter is clearly demonstrated in Polinsky's data. Third, the correct forms of cases in the speech of our participants cannot be termed 'chunks', as Polinsky defines forms such as $v$ dome, v lesu, utrom, v vode, ('in the house, ' 'in the woods, 'in the morning, ' 'in the water'). In short, 'restructuring of cases,' as Polinsky describes it, did not emerge in our data. Our findings may be better explained as a reanalysis of case functions such as direction, location, means, etc. Additional experimental study with more robust tasks such as translation and grammatical judgment is needed to account fully for the system of cases in HS language.

\subsubsection{Word Order}

While SV word order is more frequent in Russian overall, VS is particularly common in narratives and story-telling. We therefore viewed VS word order in this study as an important indicator of language proficiency. A discussion of the correlation between word order and age at arrival in the U.S. is offered in the section on the cross- group analysis (see Section 5).

The following examples illustrate VS word order use by the heritage speakers. 
(26) Тянул

tjanul

оH

on

очень сильно, так

očen' sil'no tak

pull-IMP

сильно

sil'no

strong

$\begin{array}{lll}\text { что } & \text { он } & \text { даже } \\ \text { čto } & \text { on } & \text { daže } \\ \text { that } & \text { he } & \text { even }\end{array}$

$\begin{array}{llll}\text { сам упал в } & \text { реку. } \\ \text { sam } & \text { upal } v & \text { reku } \\ \text { himself } & \text { fell in } & \text { river }\end{array}$

'He pulled very hard, so hard that even he himself fell into the river.'

(27) Сидит

sidit

Sit-IMPERF:PRES возле реки маленький мальчик.

vozle reki malen'kij mal'čik

around river little boy-NOM

'A little boy is sitting at the river.'

(28)

$\begin{array}{ll}\ldots \text { ии } & \text { теперь } \\ i & \text { teper' } \\ \text { and } & \text { now }\end{array}$

тонет

tonet

drown-IMPERF:PRES
Петька.

Pet'ka

Petka-NOM

'... and now Petka is the one drowning.'

(29)

Похоже, что клевет

poxože čto klevet

Looks like that takes (bait)-IMPERF:PRES рыба.

ryba

fish-NOM

'It looks like the fish is taking the bait.'

(30)

\begin{tabular}{|c|c|c|c|c|}
\hline $\begin{array}{l}\text { Переходя } \\
\text { perexodja } \\
\text { crossing }\end{array}$ & $\begin{array}{l}\text { через } \\
\text { čerez } \\
\text { through }\end{array}$ & $\begin{array}{l}\text { берег, } \\
\text { bereg } \\
\text { shore }\end{array}$ & $\begin{array}{l}\text { стремится } \\
\text { stremitsja } \\
\text { aim-IMPERF:PRES:REFL }\end{array}$ & $\begin{array}{l}\text { она } \\
\text { ona } \\
\text { she-NOM }\end{array}$ \\
\hline теперь & B & лес. & & \\
\hline teper' & $v$ & les & & \\
\hline now & to & woods & & \\
\hline
\end{tabular}

'Crossing the shore, she is rushing now to the woods.'
(31) ...и собаку
оттянул
i sobaku
ottjanul
мальчик маленький
mal'čik malen'kij


and dog-ACC:FEM pull:PERF:PAST:MASC boy-NOM little-NOM

'... and the little boy pulled the dog aside.'

\subsubsection{Occasionalisms on the Morphosyntactic Level}

Idiosyncratic morphosyntactic errors by HS participants were also observed. Despite their infrequent occurrence, they may provide a valuable input for analysis. We call these 'occasionalisms' due to the lack of frequency with which they appeared, but we are aware that in a narrative based on a different task, they might be quite regular.

\subsubsection{Coordinate and Subordinate Clauses}

Interestingly, the HS data show a preference for coordinate rather than subordinate clauses. We did not do a corresponding analysis on the other two groups (L2 learners and monolinguals), hence we limit ourselves to the suggestion that a preference for coordinate clauses was not surprising given that the task involved story telling (i.e., looking at one or two pictures at a time), which presupposes a narrative discourse in which events unfold in a successive manner.

\subsubsection{Reference-tracking across Clauses $^{14}$}

$\begin{array}{llllll}\text { Мальчик } & \text { бежал } & \text { обратно } & \text { с } & \text { собакой } & \text { и } \\ \text { mal'čik } & \text { bežal } & \text { obratno } & s & \text { sobakoj } & i \\ \text { boy:NOM } & \text { was running back } & \text { with } & \text { dog } & \text { and } \\ \text { oн } & & & & \\ \text { on } & & \text { держал } & \text { coбaкy. } \\ \text { he-PRON:3SG:MASC } & \text { weržal } & \text { sobaku holding } & \text { dog }\end{array}$

'The boy was running back with the dog and he was holding the dog.'

$\begin{array}{llll}\text { Он } & \begin{array}{l}\text { поймал } \\ \text { pojmal }\end{array} & \begin{array}{l}\text { рыбу } \\ \text { ry }\end{array} & \text { он on } \\ \text { He-PRON:3SG:MASC } & \text { caught } & \text { fish and he-PRON:3SG:MASC } \\ & & & \\ \text { начал } & \text { тянуть. } & \\ \text { načal } & \text { tjanut' } & \\ \text { began } & \text { to pull } & \end{array}$

'He caught the fish and started pulling.' 


\begin{tabular}{|c|c|c|c|c|c|}
\hline \multicolumn{2}{|c|}{ on } & $\begin{array}{ll}\text { xočet } & \text { ee } \\
\text { wants } & \text { her }\end{array}$ & $\begin{array}{l}\text { spasti } \\
\text { to save }\end{array}$ & $\begin{array}{l}\text { konečno } \\
\text { of course }\end{array}$ & $\begin{array}{l}i \\
\text { and }\end{array}$ \\
\hline но & $\mathbf{O H}$ & $\mathrm{He}$ & хочет & замочить & свои \\
\hline no & on & ne & xočet & zamočit' & svoi \\
\hline but & he-PRON: & SG:MASCno & want & wet & his \\
\hline
\end{tabular}

'He wants to save it, of course, but he does not want to get his clothes wet.'

In the three examples listed above, the coordinate clauses do not require repetition of the referent. In fact, monolingual speakers of Russian and English would almost certainly use a null copy in their respective languages. A plausible explanation for the redundant pronominal referent in the second and third sentences could be that these sentences describe events depicted in two different pictures (the second example additionally involves a page-turn). Thus, the repetition of the referent could be caused by the mere nature of narration, i.e., a description of each picture starts with the subject of the action even when this subject is the same as in the previous picture. On the other hand, this repetition might be a discourse-related device used by HS to secure complete understanding of the message. ${ }^{15}$

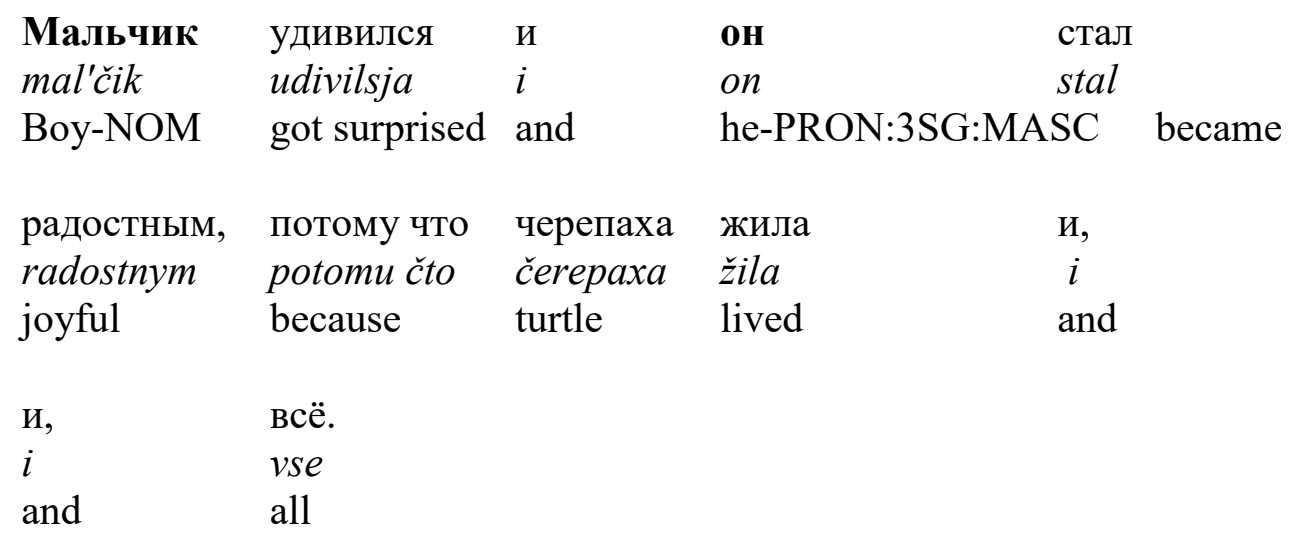

'The boy was surprised and he became happy, because the turtle lived, and that's all.'

The above example, composed of two coordinate clauses, would not require referent repetition in Russian but probably would in English. In addition, considering the nature of the described events (i.e., emotional states), it is perhaps not surprising that the speaker chose referent redundancy in order to emphasize the two emotional states of the subject. 


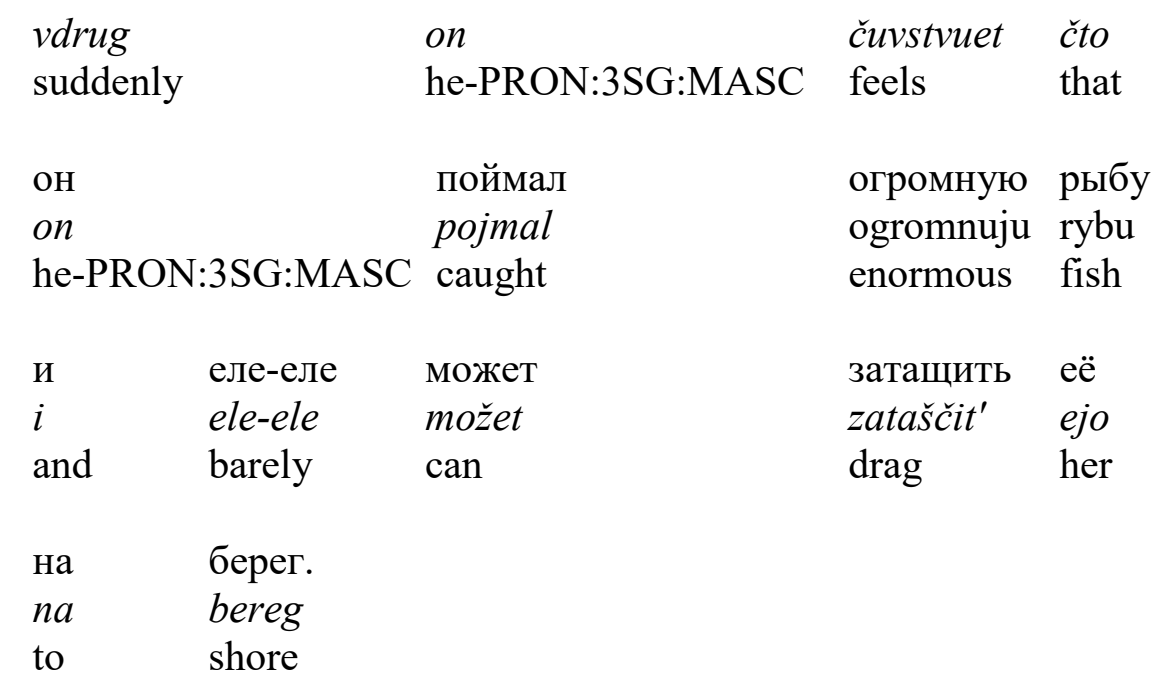

'Suddenly he feels that he caught a big fish and can barely drag it to the shore.'

Here, the repetition of the referent in the subordinate clause would be obligatory in English but is unnecessary in Russian. Thus, this could be a case of language transfer.

\begin{tabular}{|c|c|c|c|c|}
\hline $\begin{array}{l}\text { Они } \\
\text { oni } \\
\text { They:PRON:3PL }\end{array}$ & $\begin{array}{l}\text { выкопали } \\
\text { vykopali } \\
\text { dug }\end{array}$ & $\begin{array}{l}\text { яму } \\
\text { jamu } \\
\text { hole }\end{array}$ & $\begin{array}{l}\text { и } \\
i \\
\text { and }\end{array}$ & $\begin{array}{l}\text { только } \\
\text { tol'ko } \\
\text { as }\end{array}$ \\
\hline $\begin{array}{l}\text { приготовились } \\
\text { prigotovilis' } \\
\text { were getting ready }\end{array}$ & $\begin{array}{l}\text { похоронить } \\
\text { poxoronit' } \\
\text { to bury }\end{array}$ & $\begin{array}{l}\text { черепаху, } \\
\text { čerepaxu } \\
\text { turtle }\end{array}$ & $\begin{array}{l}\text { как } \\
k a k \\
\text { as }\end{array}$ & $\begin{array}{l}\text { выяснилось, } \\
\text { vyjasnilos } \\
\text { became clear }\end{array}$ \\
\hline $\begin{array}{l}\text { она } \\
\text { ona } \\
\text { she }\end{array}$ & $\begin{array}{l}\text { живая. } \\
\text { živaja } \\
\text { alive }\end{array}$ & & & \\
\hline
\end{tabular}

'They dug out a hole and just as they were getting ready to bury the turtle, it became clear that it was alive.'

The subordinate clause in the above example involves a reflexive verb, prigotovilis' ('they got ready'), which together with the presence of the conjunction tol'ko ('just') could have triggered the referent repetition. Moreover, the pronoun in the subordinate clause could be an emphatic device. 


\subsection{Lexical Findings}

Our lexical findings are limited to only three phenomena with a relatively high number of occurrences in the HS narratives. They do not show regularity or competence problems across the board; rather, they may manifest certain strategies to cope with lexical retrieval problems in unrehearsed narration.

\subsubsection{Lexical Extension}

Lexical extensions are those instances in which a single word is generalized to cover various semantically related contexts. ${ }^{16}$ There were seven instances of lexical extension in the speech samples of four of the HS participants; they are all provided below.

$\begin{array}{lllll}\text { (38) Лягушка взяла } & \text { c } & \text { собаки } & \text { лапу. } \\ \text { ljaguška } & \text { vzjala } & \text { s } & \text { sobaki } & \text { lapu } \\ \text { frog } & \text { take-PERF:PAST:FEM } & \text { from } & \text { dog } & \text { paw }\end{array}$

'The frog took the dog's paw.'

(39) Рыба взяла крючок.

Ryba vzjala krjučok

Fish take-PERF:PAST:FEM fishhook

'The fish took the fishhook.'

(40) Ему тяжело рыбу взять с нему. ети tjaželo rybu vzjat' $s$ nemu. he difficult fish to take-INF with him

'It is hard for him to take the fish with him.'

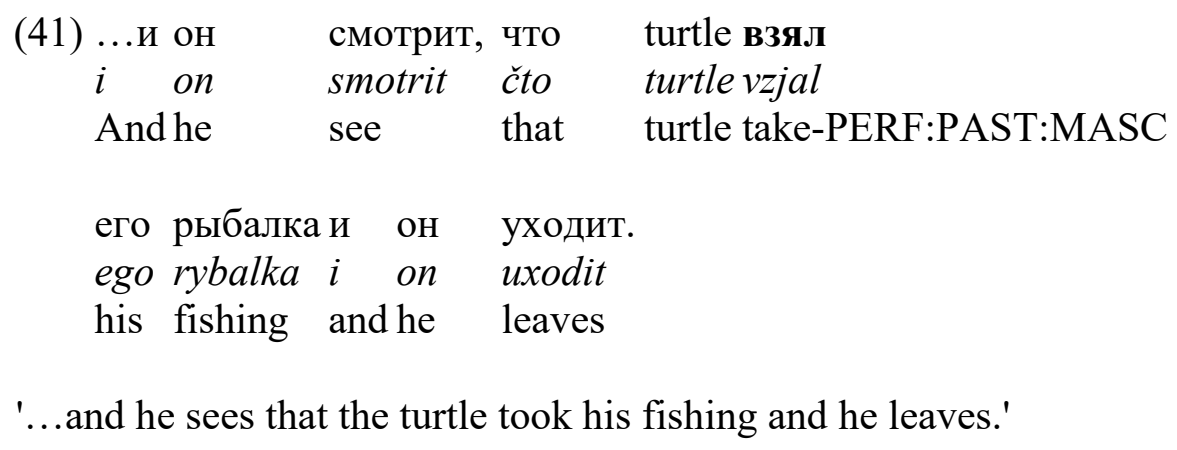


(42) И потом маленький мальчик взял что, всё что он

$i \quad$ potom malen'kij mal'čik vzjal čto vsë čto on

And then little boy took that all that he

пришел на рыбалку.

prišel na rybalku

came to fishing.

'And then the little boy picked up everything that he had with him when he came fishing.'17

\begin{tabular}{|c|c|c|c|c|c|}
\hline $\begin{array}{l}\text { (43) Когда он } \\
\text { Kogda on } \\
\text { When he }\end{array}$ & $\begin{array}{l}\text { выплавил } \\
\text { vyplavil } \\
\text { swam }\end{array}$ & $\begin{array}{l}\text { оттуда, } \\
\text { ottuda, } \\
\text { away from ther }\end{array}$ & $\begin{array}{l}\text { кажется, } \\
\text { kažetsja } \\
\text { re }\end{array}$ & $\begin{array}{l}\text { чTо } \\
\text { čto } \\
\text { seemed }\end{array}$ & $\begin{array}{l}\text { другой } \\
\text { drugoj } \\
\text { like the other }\end{array}$ \\
\hline зверь & ВЗяЛ & & его & палку. & \\
\hline $\begin{array}{l}z v e r^{\prime} \\
\text { beast }\end{array}$ & $\begin{array}{l}\text { vzjal } \\
\text { take-PERF }\end{array}$ & PAST:MASC & $\begin{array}{l}\text { ego } \\
\text { his }\end{array}$ & $\begin{array}{l}\text { palku } \\
\text { stick }\end{array}$ & \\
\hline
\end{tabular}

'When he swam away from there, it seemed that the other beast had taken his stick.'

$\begin{array}{llll}\ldots u & \text { опять } & \text { взяла } & \text { палку. } \\ \mathrm{i} & \text { opjat' } & \text { vzjala } & \text { palku } \\ \text { and } & \text { again } & \text { take-PERF:PAST:FEM } & \end{array}$

'And it took the stick again.'

It is not surprising that this particular Russian verb, vzjat' is being generalized to cover various contexts; the same verb in English ('to take') performs similar functions. A similar generalizing strategy has been used in the L2 narratives but there a different verb, polučit' ('to receive'), was used. This word choice is clearly less successful, given the passive, patient-oriented semantics of polucit' and the different conceptualization of the actions represented by lexical labels of 'take' and 'receive', both in Russian and in English.

\subsubsection{Conceptual Shift}

Another observation concerns the way heritage speakers expressed emotions, a phenomenon previously noted by Pavlenko (2002) in a study of American Russian bilinguals. According to Pavlenko, in English emotions are usually conceptualized as passive states, whereas in Russian they are conceptualized as inner activities. This conceptual difference manifested itself in the language of Pavlenko's bilinguals and that of our heritage speakers in utterances where a predicate consisted of the verb to be (which is omitted in the present tense in Russian) plus an adjective (cf. 
the examples below). We applied Pavlenko's notion of "conceptual shift" to the analysis of our HS data and detected five such instances.

(45) После борьбы posle bor'by After struggle испугана* ispugana frightened:PTL:PAST:FEM c черепахой, собака очень

$s \quad$ čerepaxoj sobaka očen'

with turtle dog very

'After the struggle/fight with the turtle, the dog is very frightened.'

*испугана [ispugana] ('to be frightened') instead of испугалась [ispugalas'] ('to become frightened')

\section{(46)}

\begin{tabular}{|c|c|c|c|c|}
\hline $\begin{array}{l}\text { Мальчик } \\
\text { mal'čik } \\
\text { boy }\end{array}$ & $\begin{array}{l}\text { удивился } \\
\text { udivilsja } \\
\text { was surprised }\end{array}$ & $\begin{array}{l}\text { и } \\
i \\
\text { and }\end{array}$ & $\begin{array}{l}\text { OH } \\
\text { on } \\
\text { he }\end{array}$ & $\begin{array}{l}\text { стал } \\
\text { stal } \\
\text { become:PERF:PAST }\end{array}$ \\
\hline $\begin{array}{l}\text { радостным } \\
\text { radostnym } \\
\text { joyful }\end{array}$ & $\begin{array}{l}\text { потому что } \\
\text { potomu } \\
\text { because }\end{array}$ & $\begin{array}{l}\text { черепаха } \\
\text { čerepaxa } \\
\text { turtle }\end{array}$ & $\begin{array}{l}\text { жила } \\
\text { žila } \\
\text { lived }\end{array}$ & $\begin{array}{lll}\text { и, и, всё } \\
i & i & v \text { sjo } \\
\text { and } & \text { and } & \text { all }\end{array}$ \\
\hline
\end{tabular}

'The boy was surprised and he rejoiced because the turtle lived, and that's all.'

*стал радостным [stal radostnym] ('became happy') instead of обрадовался [obradovalsja] ('rejoiced')

\begin{tabular}{|c|c|c|c|c|c|}
\hline $\begin{array}{l}\ldots \text { и } \\
i \\
\text { and }\end{array}$ & $\begin{array}{l}\text { маленький } \\
\text { malen'kij } \\
\text { little }\end{array}$ & $\begin{array}{l}\text { мальчик } \\
\text { mal'čik } \\
\text { bоy }\end{array}$ & $\begin{array}{l}\text { c } \\
S \\
\text { with }\end{array}$ & $\begin{array}{l}\text { собакой } \\
\text { sobakoj } \\
\text { dog }\end{array}$ & $\begin{array}{l}\text { потом } \\
\text { potom } \\
\text { then }\end{array}$ \\
\hline на ... & стоёт & там & c & собакой & И \\
\hline$n a$ & $\begin{array}{l}\text { stojot } \\
\text { stand }\end{array}$ & $\begin{array}{l}\text { tam } \\
\text { there }\end{array}$ & $\begin{array}{l}s \\
\text { with }\end{array}$ & $\begin{array}{l}\text { sobakoj } \\
\text { dog }\end{array}$ & $i$ \\
\hline $\begin{array}{l}\text { собака } \\
\text { sobaka } \\
\text { dog }\end{array}$ & $\begin{array}{l}\text { очень } \\
\text { očen' } \\
\text { very }\end{array}$ & $\begin{array}{l}\text { сонная. } \\
\text { sonnaja } \\
\text { sleepy-NC }\end{array}$ & & & \\
\hline
\end{tabular}

'... and the little boy with his dog is then standing there with the dog and the dog is very sleepy.' 


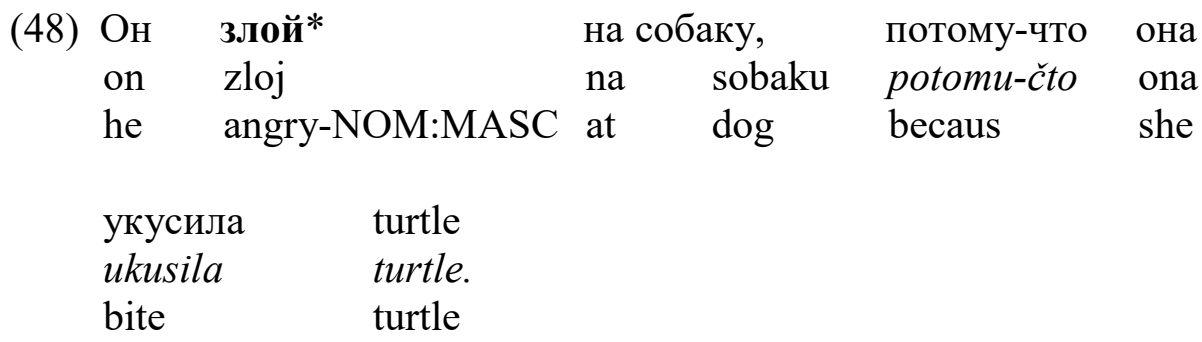

'He is angry at the dog because it bit the turtle.'

*злой [zloj] ('angry') instead of разозлился [razozlilsja] , (became angry')

Polinsky (2000a) argues that expressing certain events descriptively, with the verb to be and an adjective or noun, is a sign of an impoverished lexicon. While we agree that this might be true for her examples (e.g., 'byt' alcoholic,' 'get drunk' for napit'sja), in cases where emotions are expressed we should consider both the nature of the speaker's lexicon and the psychological mechanism of conceptual shift as observed by Pavlenko, since they are most often interrelated. In order to determine which factors played a role in producing the above examples, we must therefore look at a speaker's entire narrative and its lexical variety, including the overall scope of his/her lexicon. We should also take into consideration such psycholinguistic factors as the speaker's family background and degree of exposure to Russian. ${ }^{18}$

The last two examples in this section may indeed represent both conceptual shift and impoverished lexicon. They were produced by the speaker who was born in the U.S. and who had had the least exposure to Russian of all the HS participants. His lexicon is very small, as evidenced by the fact that he repeatedly uses a pool of "favorite" words throughout his narrative. Furthermore, he often uses English words (e.g., 'turtle,' 'frog'), invents words (polož for položil ('put'), uses incorrect, albeit semantically related, words (rybalka), ('fishing' for 'fishing rod'), and replaces specific words with more general ones (cf. more, ('sea') for reka, ('river') and vzjat' ('take') for podnjat' ('pick up'), or vytaščit' ('pull out'), etc. In addition, his grammatical proficiency is extremely low; his speech exhibits obvious imitation of English syntax (e.g., ... i idët, $i$ smotrit na gde sobaka byla ('... and he is coming, and he is looking at where the dog was'), oblique cases are almost non-existent, etc. ${ }^{19}$

\subsubsection{Word "Invention"}

In this section we analyze the word inventions of the above-mentioned heritage speaker who was born in the U.S. (Participant No. 6). In his narrative, we recorded the use of odd ("invented") forms such as son ('dream') for sonnyj ('sleepy') and polož for položil ('he put'). Recall that this is the same speaker who had difficulty retrieving lexical items, including the Russians labels for 'turtle,' 'frog', and 'fishing rod.' He also produced sentences that were clear syntactic calques from English, e.g. the preposition stranding in the fifth example under 'lexical extension' above. His word-invention strategy presents a possible mechanism for coping with grammatical, semantic and word-formation problems. In other words, by inventing new rules and/or perhaps using rudimentary rules from his mental grammar, this speaker creatively manipulates the following existing morphosyntactic and semantic rules of Russian: 
1) Use of short forms of adjectives to express temporary qualities. A standard Russian example would be the short form zanjat ('busy'), (compare the long form zanjatyj ('busy')) in a sentence such as: On segodnja zanjat ('He is busy today'). The word that our heritage speaker produced, son, means 'dream' in Russian and the adjective sonnyj ('sleepy') does not have a short form at all.

2) Use of verbal suffixes (mostly $v a$-) to form imperfectives, e.g. the aspectual pair nalit' (PERF)nalivat' (IMPERF) ('to pour'). Psychologically, for a speaker who has not mastered all of the various ways of forming aspectual pairs, and is mostly aware of aspectual pairs such as nalit'nalivat', the most natural way to form a perfective would be to use a shortened form of the imperfective. The speaker could wrongly assume that the lexicalized perfective form položit' is, in fact, imperfective and produce a non-word polož. ${ }^{20}$

\section{In-Group Analysis}

In this section we compare the data on the narrative performance of heritage speakers with the information gathered through the background questionnaire. We have plotted the linguistic data against the psycholinguistic data in order to detect relationships between grammatical inconsistencies and such psycholinguistic factors as age of arrival in the U.S. and the amount of exposure to Russian. The preliminary analysis suggested that age of arrival in the U.S. and exposure to L1 were the two primary factors contributing to variability in the participants' performance on the narrative task. However, a closer look at the exposure data shows that that this factor is more complex than simply the daily use of the language at any given time. On the one hand, all but two participants reported that they currently spoke Russian only ten percent of their time daily (Participants No. 1 and 7 reported 30\% and 40\%, respectively.) This ten percent may have comprised no more than the time our participants spent in Russian language classes, given that none of them lived permanently with their Russian speaking families any more. On the other hand, the questionnaire also revealed that only two participants (Nos. 5 and 6) speak to their parents predominantly in English, while the remaining 5 speak Russian. In addition, one participant (No. 4) spends every other summer in Russia. Thus, because of the inherent difficulties in defining and quantifying "exposure," age of arrival in the U.S. was our primary focus of analysis.

The heritage learners' age of arrival in the U.S. varied between 0 and 10, with only two participants (Nos. 2 and 3) having had 2 and 3 years of formal Russian instruction in Russia, respectively. At the time of the study all participants were enrolled in $2 \mathrm{nd} / 3 \mathrm{rd}$ year Russian classes, which in theory corresponds to intermediate language proficiency. Since proficiency level was not measured in this study and given that daily exposure to Russian was reported as mostly comparable across the group, age of arrival in the U.S. was used as the major variable, but in each case we also considered other factors, such as language spoken to parents, daily use of Russian, and contacts with Russia.

The following two categories of language deviations/errors were chosen for the in-group analysis: aspectual/tense errors and incorrect use of cases. Not only were these deviations the most common among the HS, but they may also be of further interest in the cross-group analysis. In addition, word order patterns were separately analyzed to determine the extent to which age of arrival in the U.S. may have had a detrimental effect on the acquisition of VS word order in Russian. The data 
will be presented in the following way. First, a correlation will be sought among the three structural variables effect on the acquisition of VS word order in Russian. The data will be presented in the following way. First, a correlation will be sought among the three structural variables (e.g., tense/aspect errors, case errors, and VS use), then each structural variable will be compared with the extralinguistic variable of age.

In Figure 1, case errors, tense/aspect errors and VS use are plotted for each individual participant.

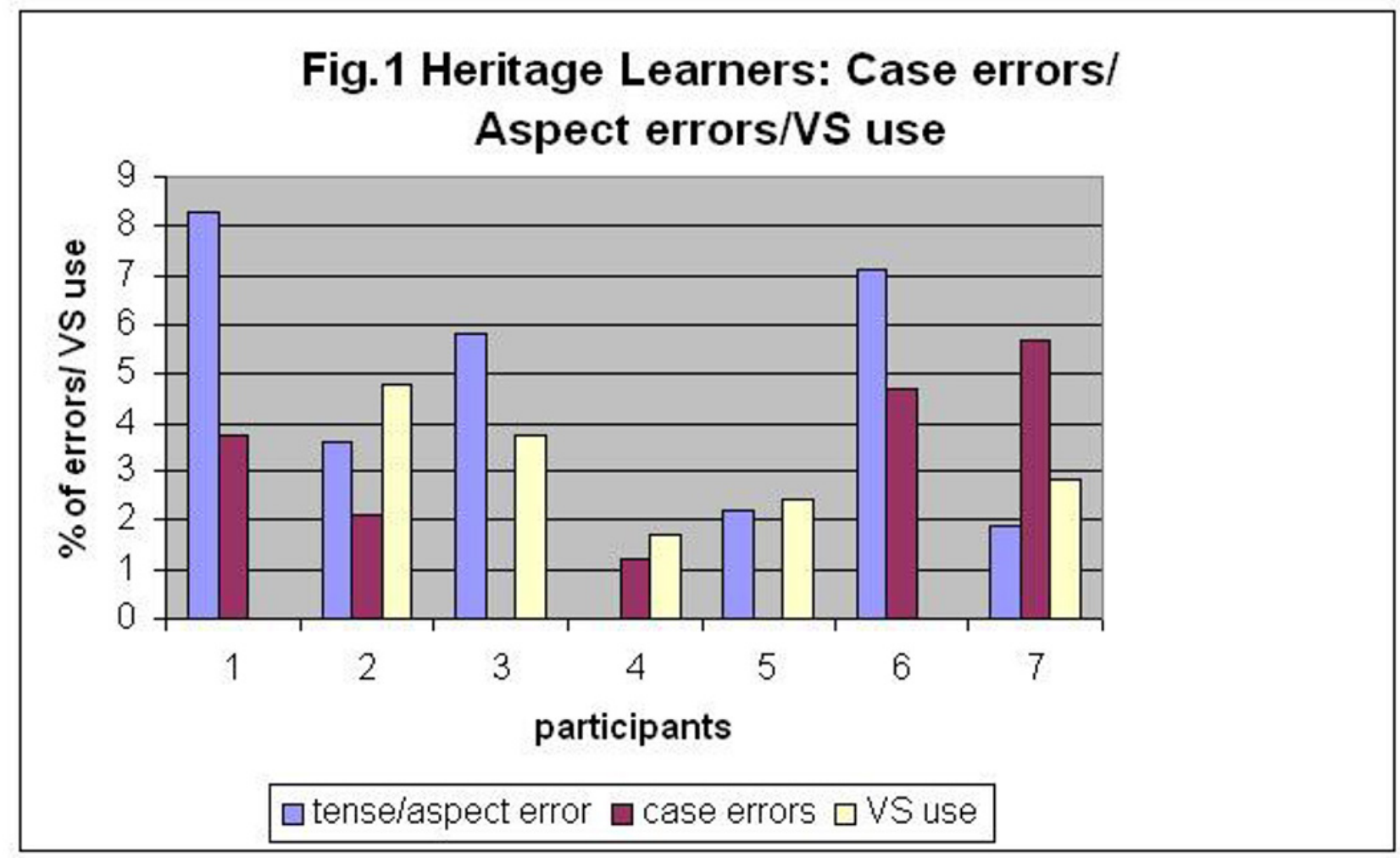

Figure 1. Heritage learners: case errors/aspect errors/VS use 
Figure 2 illustrates erroneous performance on tense/aspect with respect to age.

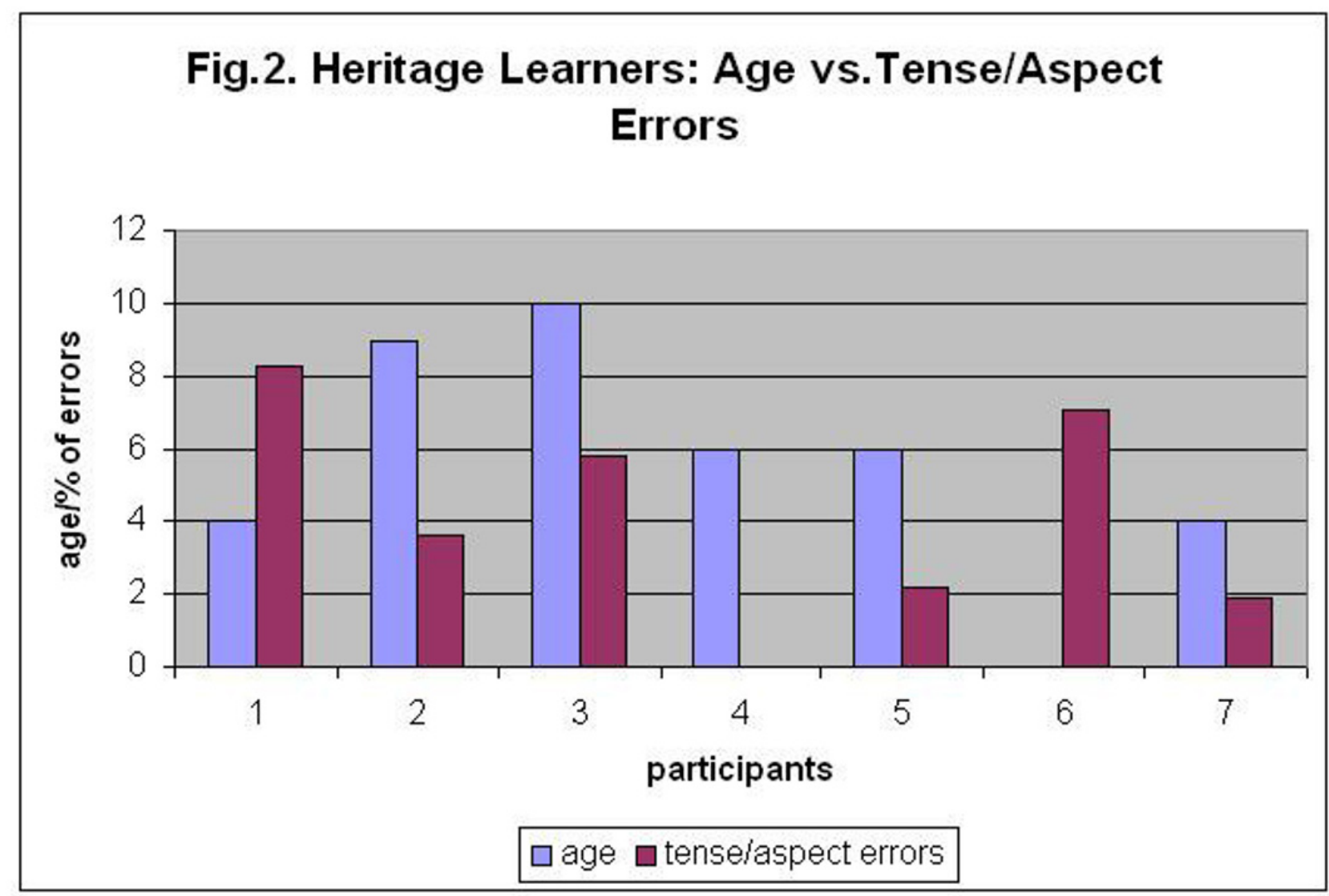

Figure 2. Heritage learners: age versus tense/aspect errors

The above data suggest a possible relationship between age of arrival in the U.S. and aspectual/tense errors. Among the heritage speakers, the age of the first exposure to English ranges from 0 (Participant No. 6 was born in the U.S.) to 10 years old. The only participant without erroneous performance was the one who regularly spends time with family in Russia (Participant No. 4). The rest of the participants did have problems correctly using tense/aspect in Russian, although there is not a linear relationship between erroneous performance and age of first exposure to English. Neither the language used for communication with parents nor age of arrival clarifies the picture. Participant No. 6, who was born in the U.S. and who speaks English to his parents, makes fewer errors (7.1\%) than Participant No. 1 (8.3\%), who came to the U.S. at the age of 4 , speaks Russian to her parents, and has a higher daily exposure to Russian (40\% versus 10\%). Given that only one participant had no problem with the correct use of tense/aspect in Russian and that that participant frequently lives with a Russian-speaking family in Russia, we hypothesize that intensive regular exposure to the language in the home country is more important for the acquisition of Russian tense/aspect than the age at arrival in the U.S. 
Figure 3 shows that case errors are negatively correlated with age of arrival, with Participant No. 3, who arrived at the age of 10, having no such instances and Participants No. 1, 6, and 7 having $3.7 \%, 4.7 \%$, and $5.7 \%$ error rates, respectively. However, it should be noted that Participant No. 5, who came to the U.S. at the age of 6 and speaks English to his parents, showed no case errors. This again suggests that age of arrival cannot be considered separately from other extralinguistic factors, such as the amount of daily exposure to L1 and the language spoken in the family.

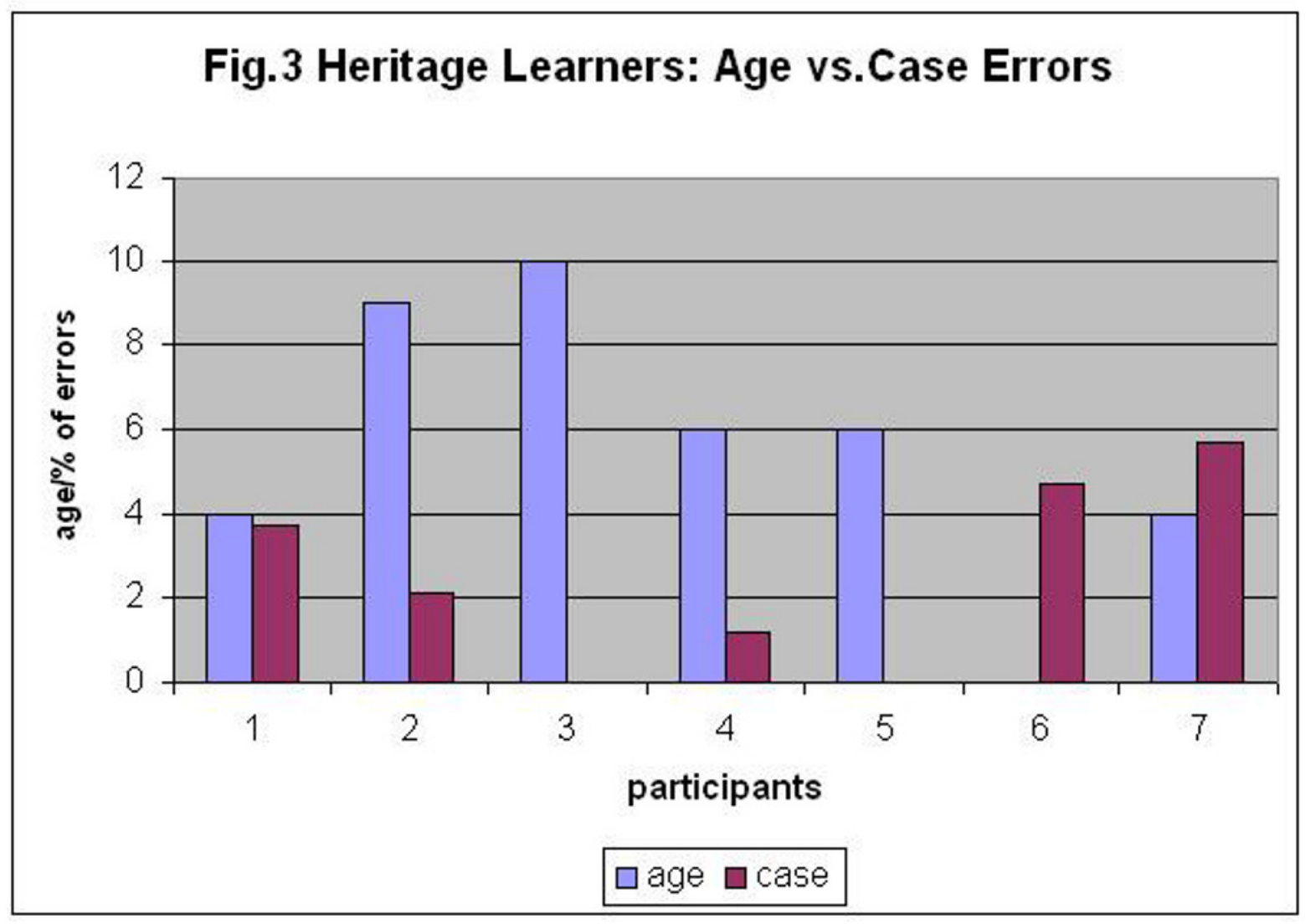

Figure 3. Heritage learners: age versus case errors

The next chart (Figure 4) portrays reverse word order plotted against the age of participants' first exposure to English. It is notable that age is positively correlated with the acquisition of reverse word order in Russian. Early exposure to narrative patterns in Russian, in which VS order predominates in story-telling, may explain the fact that the participants who were either born in the U.S. or came to the country under the age of six used the VS order less frequently or not at all (Participants No. 1 and 6). To summarize, we suggest that the acquisition of cases and VS word order may depend on age of arrival in the U.S., while the acquisition of tense/aspect may depend more on regular and extensive exposure to the target language than on the age factor. 


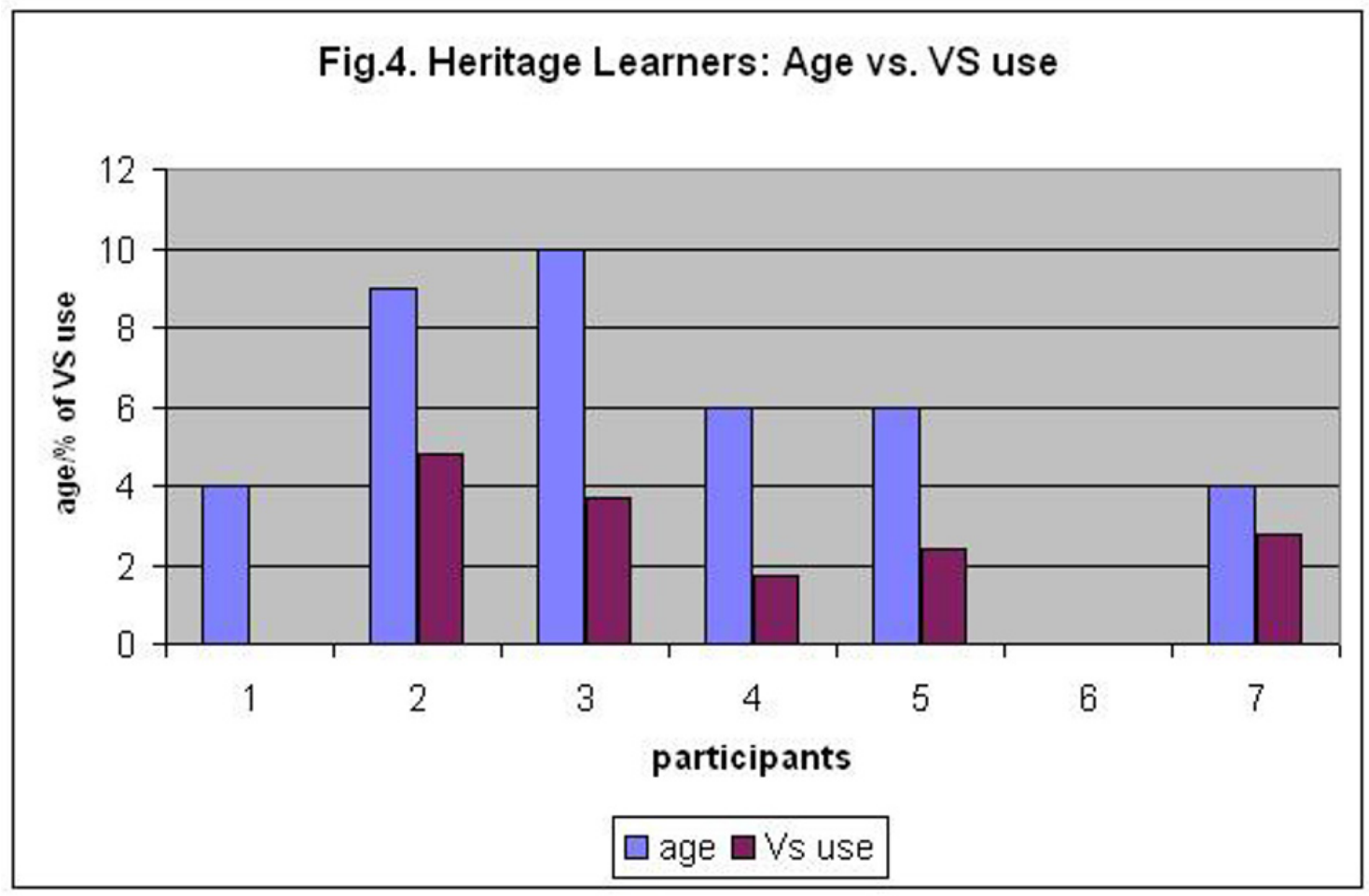

Figure 4. Heritage learners: age of arrival versus VS use

Further analysis of the questionnaire revealed that all participants are highly motivated to maintain their Russian and that their parents and family heritage encourage their interest in the language. All but one reported writing as their most problematic area. Five participants admitted having a problem with remembering Russian words, correctly conjugating verbs and using the correct case endings. This shows a high metalinguistic awareness among the participants in the heritage learner group. All 7 speakers also reported English as the language they think and dream in and the language they find easier to use when they are tired. Only one participant reported Russian as the language she switches to when she is emotional or feels like cursing. The rest chose English. This additional information suggests that the age of first exposure to the second language and the amount of daily exposure to the native language, despite their importance, should be considered along with an array of other factors that shape the ultimate performance of heritage speakers.

\section{Cross-group Analysis}

Further analysis of the data was focused on comparing the performance of the heritage speakers with that of the two other participating groups, i.e., English speakers who have studied Russian as an L2 and monolingual native speakers of Russian (the latter will be referred to as the control). Our goal is to present a more complete picture of the heritage language by comparing it to that of the other two groups. Thus, the heritage speakers in this study are seen as belonging to a continuum of speakers and not as isolated individuals. Such a comparison has been made before but with a primary focus on comparing heritage speakers and native (or monolingual) speakers. We argue that our incorporation of L2 learners offers a more detailed picture of the speaker continuum. 
The same categories examined for in-group analysis were also chosen for cross-group analysis, i.e. aspect, case, and VS word order (Table 2). We limit our discussion to summarizing the number of errors/type of word order. No detailed analysis will be given on the performance of monolinguals and L2 learners. The rate at which participants made errors with verbal aspect or cases, as well as those instances where they used the VS word order, are represented in Figure 5.

Table 2. Cross-group Comparison

\begin{tabular}{|l|l|l|l|}
\hline Participants Category & $\begin{array}{l}\text { Heritage } \\
\text { Speakers }\end{array}$ & $\begin{array}{l}\text { L2 } \\
\text { Learners }\end{array}$ & $\begin{array}{l}\text { Monolingual } \\
\text { Speakers }\end{array}$ \\
\hline Aspect & $4.1 \%$ & 12.7 & 0 \\
\hline Case & $2.4 \%$ & $6 \%$ & 0 \\
\hline VS Word Order & $2.1 \%$ & $1 \%$ & $6 \%$ \\
\hline
\end{tabular}

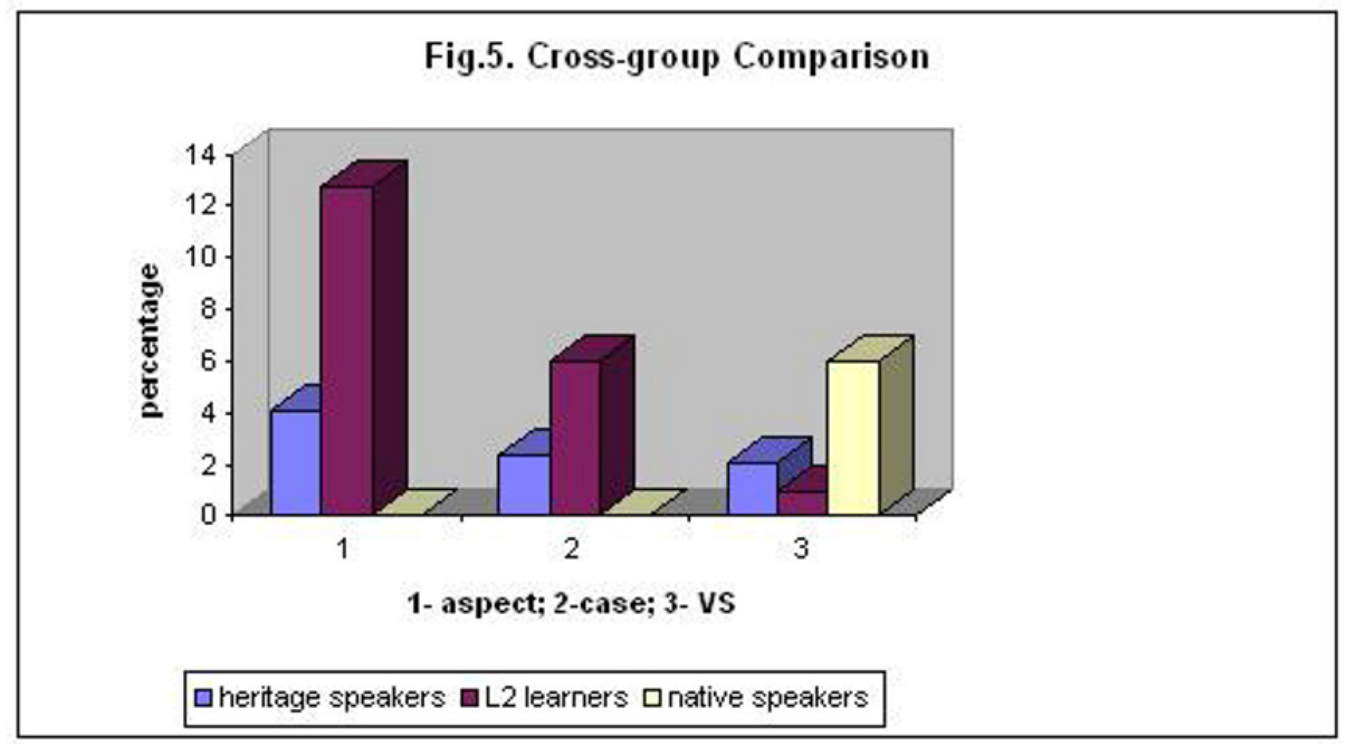

Figure 5. Cross-group comparison

Needless to say, there were no tense/aspect or case errors in the control group. As is clear from the graph (Fig. 5), the L2 learners made 3 times as many aspectual errors than the heritage speakers ( $12.7 \%$ and $4.1 \%$, respectively), and almost 3 times as many case errors ( $6 \%$ versus $2.4 \%$, respectively). It should be noted that the aspectual errors made by the L2 learners were different in kind from those made by the heritage learners. It is clear from the L2 learners' narratives that they had not mastered the use of aspectual pairs or that they lacked knowledge of a specific form (mostly perfective). As for word order, heritage speakers used VS twice as often as L2 learners but 3 times less than the control group $(2.11 \%, 1 \%$, and $6 \%$, respectively). The lower percentage 
of VS sentences produced by HS as opposed to monolingual Russians could be interpreted either as a language transfer from English or as a solution to the higher cognitive load of a VS sentence (Isurin, 2005).

When VS usage among the L2 learners is matched with the length of the L2 acquisition period, it becomes apparent that the use of Russian reverse word order increases with exposure to the language. The four L2 participants who did not use VS at all had spent only two years on L2 acquisition. ${ }^{21}$ As was previously mentioned, the acquisition of VS word order seems to depend on age of arrival in the U.S. for heritage speakers, which can be translated into the number of years spent on Russian language acquisition. Thus, we suggest that length of time spent learning the language can be crucial for the acquisition of VS order for both groups. But given the small scope of the present study, we refrain from any far-reaching conclusions.

\section{Conclusion}

As the title of our paper suggests, Russian heritage speakers may indeed be "lost in between" in the continuum of language speakers. They outperform English-speaking learners of Russian in such linguistic areas as the correct use of aspect/tense and cases, but they fall well behind the native speakers in these same areas. Moreover, they seem to be more comfortable than L2 learners in using the predominantly VS word order of Russian narrative discourse. At the same time, their mastery of that category is far from that of the native speaker. These findings are not accidental but rather are determined by the linguistic uniqueness of the population whose first language was either incompletely acquired or underwent a certain changes due to L2 influence.

The findings reported in the present study clearly show a continuum of speakers, ranging from "perfect" (the control monolingual group) to "imperfect" (the L2 learners), with the heritage speakers somewhere between the two. This observation is valuable for describing HS language more adequately and in greater detail by separating into morphosyntactic categories, while keeping in mind the bigger picture of grammatical and lexical competence.

Clearly, HS language is different from that of monolinguals and the language of L2 learners. Our paper attempted to show specific characteristics of this language as well as a possible correlation between language deviations and psycholinguistic factors such as amount of exposure to L1, age of arrival in the L2 country, etc. Given the heterogeneous nature of the Russian HS group in the U.S., and the differences in their backgrounds and language attitudes, this approach seems warranted. The results of the present study indicate that larger scale research is needed. We suggest that the pool of participants be extended, additional rigorous tasks be included, and different skills be tested, e.g., writing, speaking (interviews, film narration), translation, etc.

Our findings have implications for teachers of Russian as a foreign language, general linguists, sociolinguists, and psycholinguists who wish to attain better insight into first language learning and first language re-acquisition by Russian immigrants in the U.S. 


\section{Acknowledgement}

The authors express their gratitude to two anonymous reviewers for their valuable comments on an earlier draft of this paper. They would also like to thank Andrea Sims for editing the original version of the paper.

\section{References}

Andrews, D. R. (1999). Sociocultural perspectives on language change in diaspora. Amsterdam: John Benjamins.

Andrews, D. R. (2000). Heritage learners in the Russian classroom: Where linguistics can help. ADFL Bulletin, 31(3), 39-44.

Bermel, N., \& Kagan, O. (2000). The maintenance of written Russian in heritage speakers. In O. Kagan \& B. Rifkin (Eds.), The learning and teaching of Slavic languages and cultures, pp. 406-436. Bloomington, IN: Slavica Publishers.

Isurin, L. (2005). Cross linguistic transfer in word order: Evidence from L1 forgetting and L2 acquisition. In J. Cohen \& K. McAlista (Eds.), ISB4: Proceedings of the International Symposium on Bilingualism, pp. 1115-1130. Somerville, MA: Cascadilia Press.

Kagan, O., Akishina, T., \& Robin, R. (2002). Russian for Russians. Bloomington, IN: Slavica Publishers.

Ke, C. (1998). Effects of language background on the learning of Chinese characters among foreign language students. Foreign Language Annals, 31, 91-100.

Kondo-Brown, K. (2002). K. Family and school factors influencing academic performance of bilingual Shin Nisei students in Hawaii. In E. Tamura, V. Chattergy, \& R. Endo (Eds.), Asian and Pacific Islander American education: Social, cultural, and historical contexts, pp. 14974. South El Monte, CA: Pacific Asia Press.

Olshtain, E., \& Barzilay, M. (1991). Lexical retrieval difficulties in adult language attrition. In H. Seliger \& R. Vago (Eds.), First language attrition, pp. 139-151. Dordrecht: Foris Publications.

Pavlenko, A. (2002). Conceptual change in bilingual memory: A neoWhorfian approach. In F. Fabbro (Ed.), Advances in the neurolinguistics of bilingualism, pp. 69-94. Udine: Forum.

Polinsky, M. (2000a). The composite linguistic profile of a Speakers of Russian in the U.S. In O. Kagan \& B. Rifkin (Eds.), The learning and teaching of Slavic languages and cultures, pp. 437-465. Bloomington, IN: Slavica Publishers. 
Polinsky, M. (2000b). Language acquisition: Full and incomplete scenarios. Paper presented at the SLING2K Workshop, Bloomington, IN. Available at http://www.seelrc.org/glossos/issues/8/polinsky.pdf.

Polinsky, M. (2008). Heritage language narratives. In D. Brinton, O. Kagan, \& S. Bauckus (Eds.), Heritage language education: A new field emerging. New York: Routledge. Available at http://ling.ucsd.edu/ polinsky/pubs/frog\%20stories.pdf.

Zemskaja, E. A. (Ed.) (2001). Jazyk russkogo zarubežja [The language of the Russian diaspora]. Moscow/Vienna: Wiener Slawistischer Almanach. (Wiener slawistischer Almanach 53.)

\section{Notes}

1. The research reported in this paper was undertaken in the early spring of 2004 and the results were reported at the AATSEEL Annual Convention in Philadelphia in December, 2004. The current version is largely based on the AATSEEL presentation with a few additions to the bibliography and a broader discussion of certain topics.

2. We would like to thank an anonymous reviewer for bringing this article to our attention.

3. Our findings are based on well-known categories of morphosyntax, which have been previously discussed in different venues, cf. Lynch (2003) on Spanish heritage speakers and a review (Polinsky \& Pereltsvaig, 2003) of Zemskaja (2000). The reader may also refer to Polinsky (2000a), and Bermel and Kagan (2000).

4. For example, while Polinsky (2000a) observed a large number of resumptive pronouns in her study of American Russian, we do not observe any such pronouns. This is perhaps due to differences in the task and the setting.

5. We should note that we do not observe aspect/tense interplay in the monolingual Russian narratives. The L2 narratives, on the other hand, clearly exhibit non-mastery of the aspectual distinction, with frequent gaps in one or the other member of the aspectual opposition.

6. These three sentences were produced by one speaker. He might not have the pronominal instrumental form in his grammar.

7. We recognize the need to compare the correct use of personal pronoun cases to that of nouns in the same grammatical environment (prepositions or verbs) in order to fully understand the factors behind their use, but such a task goes beyond the present study. 
8. We realize that 'lexical gaps' is a technical term referring to a systematic absence, not to performance. However, we use this term in our study to designate problems with lexical retrieval, which may or may not be indicators of competence problems.

9. We could also argue that together with lack of a 'direction-location' distinction, these speakers have one generalized form for both 'direction' and 'location', namely, the prepositional form.

10. The same tendency (a decline in relativizing structures but verbalized in a different way) is observed by Polinsky (2000b).

11. A different case would be the sentence On idët kupat'sja $v$ more ('He's going into the sea to swim'), where the noun more ('sea') is viewed as a 'container' noun (in cognitive terms). Alternatively, the guest editor of this issue has suggested that the case error above could be due to gender confusion, a phenomenon discussed in the companion article by Maria Polinsky. According to this approach, the speaker was treating neuter more as it if were feminine morja and then declining it like a feminine noun. This explanation is attractive and plausible, but we refrain from further comment because of the lack of other (similar) cases of gender transfer in our HS samples and the inaccessibility of Polinsky's paper prior to our final editing.

12. Note here the self-corrected form of the prepositional case.

13. Cf. Polinsky's (2000a, 2000b) discussion of the reduction of cases in American Russian.

14. We adopt the term 'reference-tracking' from Polinsky's discussion of null copying across clauses in Polinsky (2000b, p. 23).

15. Cf. Polinsky's conclusion about the avoidance of null copying in AR: "Overall, it seems that the elimination of null copying is due to the general increase of redundancy rules observed in American Russian: the speaker who lacks confidence that the message will be parsed and decoded properly, introduces more 'instructional' elements that are supposed to guide the hearer in the processing" (Polinsky, 2000b, p. 23).

16. Cf. the same phenomenon observed by Bermel and Kagan (2000) in HS writing.

17. This sentence is also a syntactic calque from English involving preposition stranding (or extraction), almost always impermissible in standard Russian. In this utterance the speaker obviously imposes the English mechanism of extraction onto Russian. However, he is also trying to mask it by not allowing the overt preposition $c$ 'with' at the end of the sentence, but rather implying it as a silent copy. A total of six syntactic calques appeared in the HS data, distributed among five of the participants.

18. We employ this procedure not only in this section but also in the other sections, which deal with aspect, case, word order, etc. We do not describe every single heritage speaker the way we 
do in this section due to space limitations, but we do present general findings at the end of the paper.

19. For further analysis of the relationship between lexical proficiency and grammatical level, cf. Polinsky (2000a).

20. The perfective form of this particular verb is lexicalized for this speaker, perhaps due to its greater frequency in regard to accomplished (telic) actions.

21. Unlike the other L2 speakers in the study, these four had probably not yet attained a proficiency level of intermediate-high. 